\title{
Response of nitrogen fractions in the rhizosphere and bulk soil to organic mulching in an urban forest plantation
}

\author{
Xiaodan Sun ${ }^{1,2,3} \cdot$ Gang Wang ${ }^{1,2}$ - Yuqian Ye $\mathrm{Y}^{1,2}$. \\ Qingxu $\mathrm{Ma}^{3} \cdot$ Qingwei Guan ${ }^{1,2} \cdot$ Davey L. Jones ${ }^{3}$
}

Received: 5 August 2020 / Accepted: 4 December 2020 / Published online: 18 March 2021

(C) The Author(s) 2021

\begin{abstract}
Nitrogen is an essential component in forest ecosystem nutrient cycling. Nitrogen fractions, such as dissolved nitrogen, ammonium, nitrate, and microbial biomass nitrogen, are sensitive indicators of soil nitrogen pools which affect soil fertility and nutrient cycling. However, the responses of nitrogen fractions in forest soils to organic mulching are less well understood. The rhizosphere is an important micro-region that must be considered to better understand element cycling between plants and the soil. A field investigation was carried out on the effect of mulching soil in a 15-year-old Ligustrum lucidum urban plantation. Changes in total nitrogen and nitrogen fractions in rhizosphere and bulk soil in the topsoil (upper $20 \mathrm{~cm}$ ) and in the subsoil $(20-40 \mathrm{~cm})$ were evaluated following different levels
\end{abstract}

Project funding: This study was supported by the National Natural Science Foundation of China (No. 31971453); Priority Academic Program Development of Jiangsu Higher Education Institutions (PAPD); and Postgraduate Research \& Practice Innovation Program of Jiangsu Province.

The online version is available at http:// www.springerlink.com

Corresponding editor: Zhu Hong

Supplementary Information The online version contains supplementary material available at https://doi.org/10.1007/ s11676-021-01310-2.

Qingwei Guan

guanjapan999@163.com

1 College of Biology and the Environment, Nanjing Forestry University, Nanjing 210037, People's Republic of China

2 Co-Innovation Center for Sustainable Forestry in Southern China, Nanjing 210037, People's Republic of China

3 School of Natural Sciences, Bangor University, Bangor LL57 2UW, Gwynedd, UK of mulching, in addition to nitrogen contents in fine roots, leaves, and organic mulch. The relationships between nitrogen fractions and other measured variables were analysed. Organic mulching had no significant effect on most nitrogen fractions except for the rhizosphere microbial biomass nitrogen $(\mathrm{MBN})$, and the thinnest $(5 \mathrm{~cm})$ mulching layer showed greater effects than other treatments. Rhizosphere MBN was more sensitive to mulching compared to bulk soil, and was more affected by soil environmental changes. Season and soil depth had more pronounced effects on nitrogen fractions than mulching. Total nitrogen and dissolved nitrogen were correlated to soil phosphorus, whereas other nitrogen fractions were strongly affected by soil physical properties (temperature, water content, bulk density). Mulching also decreased leaf nitrogen content, which was more related to soil nitrogen fractions (except for MBN) than nitrogen contents in either fine roots or organic mulch. Frequent applications of small quantities of organic mulch contribute to nitrogen transformation and utilization in urban forests.

Keywords Rhizosphere - Nitrogen fraction - Organic mulching $\cdot$ Soil-plant interaction $\cdot$ Urban plantation forest

\section{Introduction}

Organic mulching plays an important role in urban soil nutrient conservation and restoration. It is an effective means to modify the structure of soil ecosystems, which is necessary to ensure that these ecosystems function properly. In addition to its physical effects such as water conservation and temperature regulation, organic mulching contributes carbon $(\mathrm{C})$ and nutrients to the soil, with the interaction of multiple factors resulting in complex mechanisms responsible for changes in the soil environment (Kader et al. 2017). 
Organic mulching improves soil conditions and promotes plant growth (Jiménez et al. 2017; Pal and Mahajan 2017). However, most studies that have evaluated the effects of organic mulching on the soil environment have tended to focus on agricultural soils, whereas studies on these effects in forest ecosystems, which may be characterised by markedly contrasting dynamics, are rare.

Nitrogen $(\mathrm{N})$ plays a prominent role in controlling the primary production of plants in terrestrial ecosystems (Guignard et al. 2017). Enhanced plant $\mathrm{N}$ uptake reduces $\mathrm{N}$ leaching loss and increases $\mathrm{N}$ availability through root exudates by stimulating the microbial turnover of fast-cycling $\mathrm{N}$ pools (Meier et al. 2017). Nevertheless, the accumulation of nitrate as a consequence of continuous $\mathrm{N}$ addition tends to cause soil acidification (Lucas et al. 2011), which can have inhibitory effects on microbial activities related to plant growth and $\mathrm{N}$ fixation (Vitousek et al. 1997). However, there is controversy regarding the response of $\mathrm{N}$ fractions to mulching or organic matter addition (Coppens et al. 2006; Rose et al. 2016). The quantity and fractions of $\mathrm{N}$ are strongly affected by plant litter (Zhou et al. 2015). Numerous studies have found that litter is an important $\mathrm{C}$ source for soil microorganisms, and litter quality, determined by $\mathrm{C}: \mathrm{N}$ ratios, phenolic compounds, or soluble $\mathrm{C}$ or $\mathrm{N}$ content and quantity, can affect $\mathrm{N}$ mineralization and nitrification (Templer et al. 2003; Meier and Bowman 2008). At the same time, root exudates and root turnover are also the main factors controlling soil $\mathrm{N}$ transformation (Huang et al. 2013). Thus, the underlying mechanisms of $\mathrm{N}$ changes are complex and remain to be confirmed.

Soil total N (TN) is a primary factor determining soil fertility and plant growth in forests, whereas labile $\mathrm{N}$ fractions determine the content of soil available $\mathrm{N}$ and nutrient cycling processes (Pastor and Post 1986). The available $\mathrm{N}$ in soil, in the form of ammonium or nitrates, is strongly correlated with TN (Turner et al. 2017). Dissolved N (DN) undergoes rapid changes in response to environmental variability, and microbial biomass $\mathrm{N}(\mathrm{MBN})$ is considered to comprise the largest labile soil organic $\mathrm{N}$ fractions, and thus their turnover significantly contributes to the soil $\mathrm{N}$ cycle (Zhou and Wang 2015; Ren et al. 2016). Investigating these $\mathrm{N}$ fractions can contribute to a more comprehensive understanding of how $\mathrm{N}$ dynamics and the stability of soil $\mathrm{N}$ pools change in response to different land management practices.

Soil $\mathrm{N}$ transformation is regulated by microorganisms (Chen et al. 2018), and microbial sensitivity to seasonal changes can be associated with temperature and $\mathrm{N}$ dynamics (Yokobe et al. 2018). Labile $\mathrm{N}$ fraction pools and net ammonification and nitrification rates in forest soils have been found to undergo substantial temporal variations driven by differences in temperature and precipitation over the year (Kaiser et al. 2011), thus the time of year should be considered in studies of soil $\mathrm{N}$ dynamics. The spatial variability of soil properties is affected by multiple factors. Nitrogen transformation rates have been found to decrease with soil depth in response to a reduction in organic matter content (Wild et al. 2015). External anthropogenic interference, such as the application of straw mulch or forage, affects the topsoil more directly than the subsoil because of the closer contact and nutrient addition, resulting in comparatively higher contents of TN and available $\mathrm{N}$ in the topsoil (Fu et al. 2019). Subsoil organic matter is derived from the retention of organic matter that is transported with percolating water (Mikutta et al. 2019), and the changes in subsoil properties (e.g., mineral $\mathrm{N}$ content) are similar to or greater than those in the topsoil (Wang et al. 2019). Accordingly, with respect to the stable $\mathrm{N}$ pool, there may be equivalent or greater changes in the subsoil compared with those in the topsoil. Thus, if the soil is to be managed sustainably, it is necessary to monitor and predict changes in soil properties throughout the entire soil profile (Usowicz and Lipiec 2017).

Organic mulching has the notable effect of enhancing plant growth as a consequence of promoting an increase in the absorption of nutrients, which in turn can lead to a modification in the soil environment via the secretion of root exudates synthesised in response to the subsequent changes in plant nutrient cycling (Kuzyakov and $\mathrm{Xu}$ 2013). The environmental complexity driven by plant-soil interactions increases after mulching. Although the individual effects of relatively few plant factors have been observed, they have been found to show interactive effects with soil factors (Chen et al. 2016b); however, such plant-soil interactions are rarely considered. As an important micro-region of chemical exchange and energy flow between plants and the soil, the rhizosphere constitutes an important zone for plant-microbial interactions. Examining this micro-region can also provide valuable insights into $\mathrm{N}$ cycling in soil and plant ecosystems (Kuzyakov and $\mathrm{Xu} 2013$ ). However, to date, there has been no study investigating changes in the rhizosphere environment in response to organic mulching. Accordingly, the response of $\mathrm{N}$ fractions to organic mulching in rhizosphere and bulk soil were determined to further understand the $\mathrm{N}$ cycle between plants and soil, and to find a suitable level of mulching for urban forest management. We hypothesised that organic mulching would significantly stimulate $\mathrm{N}$ fractions, with the effects being dependent on the amount of applied mulch; that MBN would be the most sensitive $\mathrm{N}$ fraction responding to organic mulching; that $\mathrm{N}$ fractions in the rhizosphere would be more sensitive than those in the bulk soil; and that more organic mulch would have a pronounced effect on soil $\mathrm{N}$ transformation because of the more nutrient input. 


\section{Materials and methods}

\section{Study site}

The experimental plot was located in Xiaolingwei, Xuanwu District, Nanjing, China $\left(32^{\circ} 02^{\prime} 37^{\prime \prime}-32^{\circ} 02^{\prime} 39^{\prime \prime} \mathrm{N}\right.$, $118^{\circ} 49^{\prime} 41^{\prime \prime}-118^{\circ} 49^{\prime} 43^{\prime \prime} \mathrm{E}, 37 \mathrm{~m}$ a.s.l, flat terrain) (Fig. 1). The study site lies within the northern subtropical monsoon climate zone which is characterised by distinct seasons, with an annual precipitation of $1000-1050 \mathrm{~mm}$, an annual average temperature of $15.4^{\circ} \mathrm{C}$, and an annual average $2213 \mathrm{~h}$ of sunshine. According to the historical records of Zhongshan Cemetery in Nanjing, buildings were originally located on the area; however, these were later demolished and the region was subsequently covered with forest plantations established on $50-60 \mathrm{~cm}$ of soil. For the purposes of the present study, a 15-year-old pure Ligustrum lucidum W. T. Aiton (broad-leaf privet; family, Oleaceae) plantation was selected in which trees were $>2 \mathrm{~m}$ apart and with a canopy density of approximately $85 \%$. The average tree height was $7.5 \mathrm{~m}$, and the average diameter at breast height $10.9 \mathrm{~cm}$. The basic physical and chemical properties of the soil at the site are shown in Table 1.

\section{Experimental design}

Four adjacent trees were randomly selected to establish one experimental plot (Fig. 2), and 32 such plots were established in total. According to the "Technical specification for the application of organic mulch on urban and rural greening" of Shanghai, China, and related literature (Dietrich et al. 2019; Zhang et al. 2020), we applied three treatments: 35,70 , and $140 \mathrm{~kg}$ of mulch/tree, along with a crosscheck control (CK) without mulch. The organic mulch extended evenly $80 \mathrm{~cm}$ away from the trunk, allowing for a buffer $(>0.5 \mathrm{~m})$ between the trees, and was carefully mounded around each tree as uniformly as possible to a height of 5, 10 , or $20 \mathrm{~cm}$ above the ground (OM5, $35 \mathrm{~kg}$ mulch; OM10, $70 \mathrm{~kg}$ mulch; OM20, $140 \mathrm{~kg}$ mulch). Treatment was completed by the end of November 2017. The organic mulch used was urban garden litter that had been semi-decomposed (Shanghai Moqi Garden Co., Ltd., Shanghai, China), the basic physical and chemical properties of which are shown in Table 2.

\section{Data collection}

Soil and plant samples were collected 6, 9, and 12 months after mulching (i.e., May, August, and November 2018),

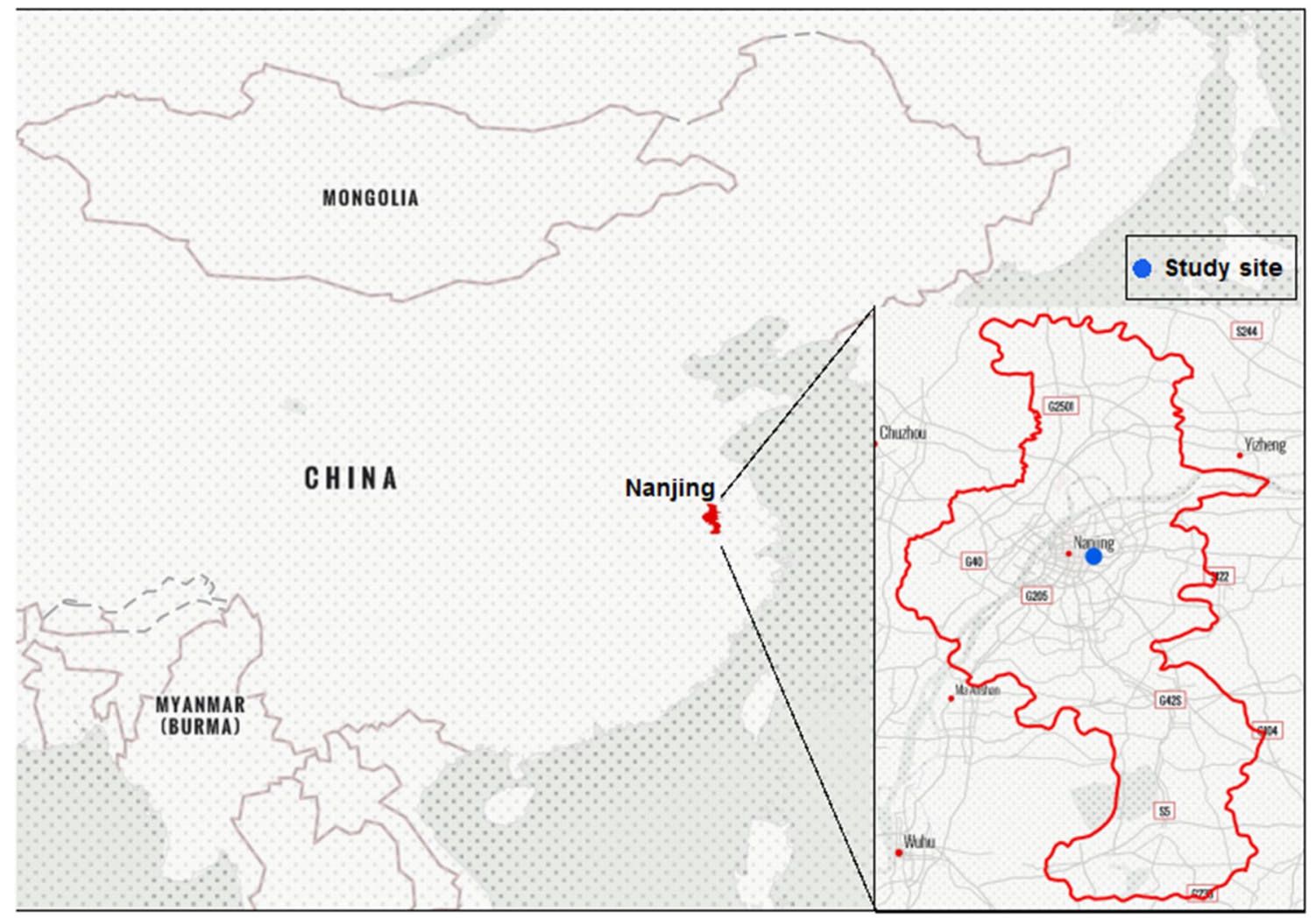

Fig. 1 Diagrammatic sketch of the geographical location of the study site 


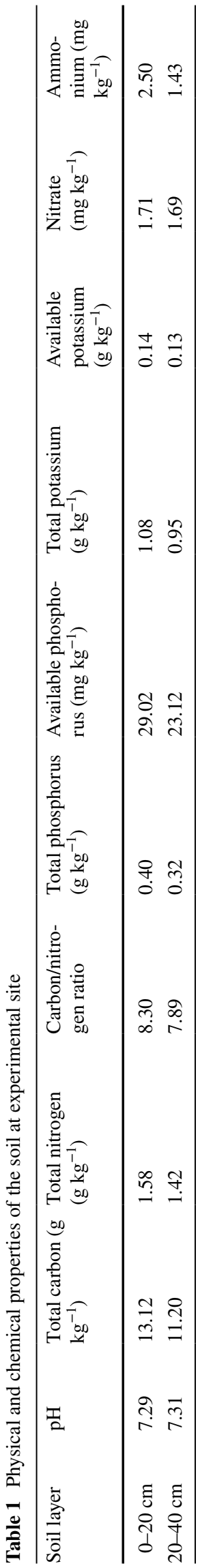

with five randomly selected plots (i.e., five replicates, one plot per replicate) for each treatment at each time point. Each experimental plot was only used once during the entire experiment, and 20 trees were used for one sample. Soil profiles were obtained from pits dug $50 \mathrm{~cm}$ away from the trunk of the tree, and each profile was divided into two sections $(0-20 \mathrm{~cm}$ and $20-40 \mathrm{~cm}$ below the mulch layer). Soil blocks $20 \times 20 \times 20 \mathrm{~cm}^{3}$ were removed from each depth, and the rhizosphere soil was collected by gently shaking off soil that had adhered to the roots, whereas the remainder of the soil was considered as bulk soil. In addition, in each plot, fine roots $(<2 \mathrm{~mm}$ in diameter) and leaves from the sampled trees were collected, as well as samples of organic mulch. All soil and plant samples were placed in self-sealing bags and taken to the laboratory for analysis. Soil samples were also obtained using cylindrical steel cores $\left(100 \mathrm{~cm}^{3}\right)$ for the determination of bulk density (BD) of each soil profile. Soil temperatures at each depth were recorded in situ using Thermochron temperature loggers (DS1923Hygrochron, OnSolution Pty Ltd, Baulkham Hills, NSW, Australia).

Estimates of soil $\mathrm{pH}$ were obtained from 1:2.5 soil-water mixtures using a PHS-3C glass electrode $\mathrm{pH}$ meter (Leici Inc., Shanghai, China). After air-drying, the samples were sifted ( $0.15 \mathrm{~mm}$ mesh), and soil organic carbon (SOC) and TN calculated using an Elemental Vario EL element analyser (Elementar, Langenselbold, Germany). Dissolved nitrogen (DN) was extracted with $0.5 \mathrm{M} \mathrm{K}_{2} \mathrm{SO}_{4}$ and determined using a TOC-VCPH + TNM-1 organic carbon analyser (Shimazu Inc., Kyoto, Japan). Ammonium and nitrate were both identified colorimetrically in $1 \mathrm{M}$ $\mathrm{KCl}$ extracts $(1: 5 \mathrm{w} / \mathrm{v})$ using a $\mathrm{San}++$ continuous flow analyser (Skalar, Breda, Netherlands). Microbial biomass $\mathrm{N}\left(\mathrm{MBN} ; \mathrm{K}_{\mathrm{N}}=0.54\right)$ was obtained using chloroform fumigation- $\mathrm{K}_{2} \mathrm{SO}_{4}$ extraction methods and calculated using the aforementioned organic carbon analyser. Total phosphorus (TP) was determined by digestion with $\mathrm{H}_{2} \mathrm{SO}_{4}-\mathrm{HClO}_{4}$ and quantified based on molybdenum blue colorimetry. Available phosphorus (extracted with $0.03 \mathrm{M} \mathrm{NH}_{4} \mathrm{~F}-0.02 \mathrm{M} \mathrm{HCl}$ ) was identified by molybdenum blue colorimetry. Total potassium was determined by inductively coupled plasmaatomic emission spectroscopy ICP-AES (ICAP6300, Thermo Fisher Scientific, Waltham, MA, USA) after wet digestion with $\mathrm{HClO}_{4}-\mathrm{HF}$. Available potassium was extracted with $1 \mathrm{M} \mathrm{CH}_{3} \mathrm{COONH}_{4}(\mathrm{pH}=7.0)$ solution and measured by ICP-AES after filtering. Soil organic matter was determined after digestion by the $\mathrm{K}_{2} \mathrm{Cr}_{2} \mathrm{O}_{7}$ titration method, and soil moisture content by oven drying samples at $105{ }^{\circ} \mathrm{C}$. Collected fine roots and leaves were washed and oven- dried. The organic mulch samples were air-dried, ground, and sifted $(0.15 \mathrm{~mm}$ mesh), and the $\mathrm{N}$ content determined using the aforementioned element analyser. 
Fig. 2 Diagrammatic sketch of experimental plots

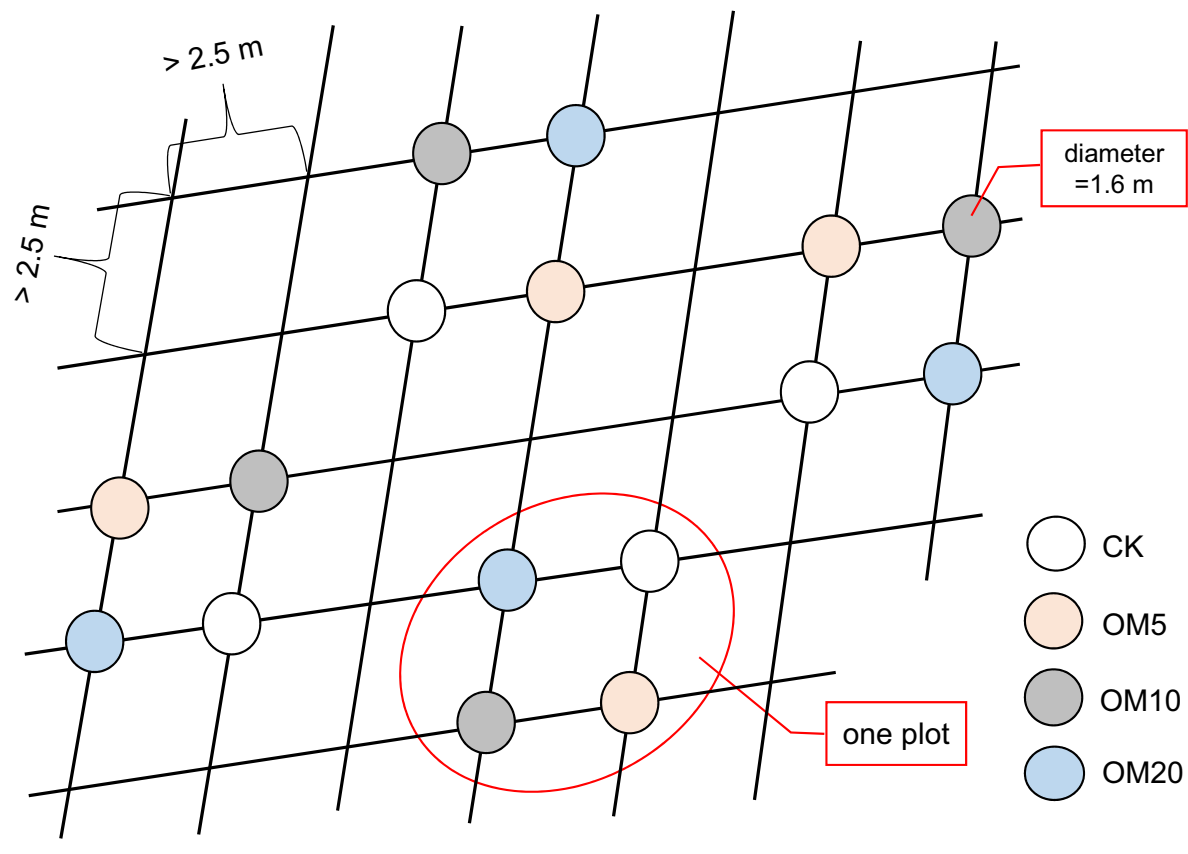

Table 2 Physicochemical properties of the organic mulch used in the study

\begin{tabular}{|c|c|c|c|c|c|c|c|c|c|}
\hline $\mathrm{pH}$ & $\begin{array}{l}\text { Dry density } \\
\left(\mathrm{g} \mathrm{cm}^{-3}\right)\end{array}$ & $\begin{array}{l}\text { Wet density } \\
\left(\mathrm{g} \mathrm{cm}^{-3}\right)\end{array}$ & $\begin{array}{l}\text { Electrical } \\
\text { conductivity } \\
\left(\mathrm{mS} \mathrm{cm}^{-1}\right)\end{array}$ & $\begin{array}{l}\text { Porosity }\left(\mathrm{m}^{3}\right. \\
\left.\mathrm{m}^{-3}\right)\end{array}$ & $\begin{array}{l}\text { Organic mat- } \\
\text { ter }\left(\mathrm{g} \mathrm{kg}^{-1}\right)\end{array}$ & $\begin{array}{l}\text { Total carbon } \\
\left(\mathrm{g} \mathrm{kg}^{-1}\right)\end{array}$ & $\begin{array}{l}\text { Total nitro- } \\
\text { gen }\left(\mathrm{g} \mathrm{kg}^{-1}\right)\end{array}$ & $\begin{array}{l}\text { Total phos- } \\
\text { phorus (g } \\
\mathrm{kg}^{-1} \text { ) }\end{array}$ & $\begin{array}{l}\text { Total potas- } \\
\text { sium }\left(\mathrm{g} \mathrm{kg}^{-1}\right)\end{array}$ \\
\hline 6.40 & 0.14 & 0.79 & 1.35 & 317.80 & 902.00 & 598.50 & 23.80 & 4.30 & 19.50 \\
\hline
\end{tabular}

\section{Statistical analysis}

All statistical analyses were conducted using R v. 3.5.3 (R Development Core Team 2018). To evaluate the differences in soil $\mathrm{N}$ fractions among treatments, time after mulching, soil depth, and their interactions, linear mixed effects models were calculated using the R package "Ime4" (Bates et al. 2015). Treatment (four levels), soil depth (two levels), time after organic mulching (season, three levels), and their interactions (three-way) were treated as fixed factors, and the sampling plots were treated as random factors. Comparisons of the $\mathrm{N}$ fractions and $\mathrm{N}$ content in fine roots, leaves, and organic mulch between treatments were carried out using two-way analyses of variance (ANOVA) and Tukey's pair-wise comparison tests. Figure preparation and redundancy analysis (RDA) were conducted using the 'ggplot2' and 'vegan' (Oksanen et al. 2019) packages in R, respectively. Comparisons of soil $\mathrm{N}$ fractions between the rhizosphere and bulk soils were performed using $t$-tests. Differences were considered to be statistically significant at the $P<0.05$ level.

\section{Results}

\section{Effects of organic mulching on soil $\mathbf{N}$ fractions in rhizosphere and bulk soils}

Time after mulching and soil depth had significant effects on $\mathrm{N}$ fractions, whereas the effects of different mulching treatments were detected only with respect to rhizosphere MBN (Table 3). Rhizosphere MBN with OM5 was significantly higher than those of the other two treatments and CK, mainly 6 months after organic mulching (Fig. 3). The interactions of time, depth, and mulching had a significant effect on TN in bulk soil and DN and nitrate in the rhizosphere. Seasonal variation in the $\mathrm{N}$ fractions in rhizosphere and bulk soil were consistent at different soil depths, although changes in the rhizosphere were more pronounced than those in bulk soil, particularly for MBN. With an increase in time after mulching, there was a gradual decrease in MBN, the seasonal variation of which was similar to that observed for TN. Ammonium content was highest 12 months after mulching, whereas values of DN and nitrate content were found to be highest 9 months after mulching. Organic mulching had 
Table 3 Analysis of variance of the effects of different treatments, depths, and time on soil nitrogen fractions

\begin{tabular}{|c|c|c|c|c|c|c|}
\hline Soil & Factors & Total nitrogen & Dissolved nitrogen & Ammonium & Nitrate & $\begin{array}{l}\text { Microbial bio- } \\
\text { mass nitrogen }\end{array}$ \\
\hline \multirow[t]{7}{*}{ Bulk soil } & Time & $10.72 * * *$ & $149.77 * * *$ & $912.47 * * *$ & $343.54 * * *$ & $276.10 * * *$ \\
\hline & Depth & $18.81 * * *$ & $18.42 * * *$ & $7.55 * *$ & $15.27 * * *$ & $128.30 * * *$ \\
\hline & Treatment & 0.06 & 2.05 & 1.92 & 1.10 & 2.67 \\
\hline & Time $\times$ Depth & 0.51 & 0.43 & 1.78 & 0.45 & $55.77 * * *$ \\
\hline & Time $\times$ Treatment & 0.70 & $2.74 *$ & 0.53 & 1.52 & 0.93 \\
\hline & Depth $\times$ Treatment & 1.66 & 1.31 & 0.38 & 0.21 & 0.14 \\
\hline & Time $\times$ Depth $\times$ Treatment & $2.63 *$ & 0.44 & 0.43 & 0.97 & 0.04 \\
\hline \multirow[t]{7}{*}{ Rhizosphere } & Time & $4.38 *$ & $125.28 * * *$ & $157.33 * * *$ & $383.92 * * *$ & $719.22 * * *$ \\
\hline & Depth & $13.47 * * *$ & $37.07 * * *$ & $33.00 * * *$ & $17.38 * * *$ & $102.95 * * *$ \\
\hline & Treatment & 0.01 & 2.55 & 0.62 & 0.01 & $16.14 * * *$ \\
\hline & Time $\times$ Depth & 1.09 & 0.48 & $6.56 * *$ & 0.15 & $10.00 * * *$ \\
\hline & Time $\times$ Treatment & 0.22 & $2.62 *$ & 0.62 & 0.50 & $8.09 * * *$ \\
\hline & Depth $\times$ Treatment & 0.47 & $3.66^{*}$ & 2.33 & 0.53 & 0.01 \\
\hline & Time $\times$ Depth $\times$ Treatment & 0.33 & $2.51 *$ & 1.61 & $2.63 *$ & 0.39 \\
\hline
\end{tabular}

$F$ values are reported with $p$ values indicated as follows: $* P<0.05 ; * * P<0.01 ; * * * P<0.001$

greater effects on the $\mathrm{N}$ fractions in the subsoil $(20-40 \mathrm{~cm})$ than that in the topsoil $(0-20 \mathrm{~cm})$, especially for DN and MBN. The OM5 treatment had the highest effects on MBN as well as on DN in the subsoil.

\section{Changes in the $\mathbf{N}$ contents of fine roots, leaves, and organic mulch}

Nitrogen levels in fine roots increased and in organic mulch decreased gradually over time, but the difference of $\mathrm{N}$ in fine roots and organic mulch between treatments was not significant (Fig. 4). Leaf N content decreased 6 months after mulching, later increased, and subsequently decreased again in the dormant season. OM10 and OM20 had significant effects on leaf N 6 months and 12 months after mulching, respectively, whereas it was 9 months after mulching for OM5 and OM20 compared with other treatments.

\section{Association of $\mathbf{N}$ fractions with soil and plant properties}

Redundancy analysis indicated a significant positive correlation between each $\mathrm{N}$ fraction in the rhizosphere and the corresponding fraction in bulk soil (Fig. 5 and Table S1 in Supplementary information). Total $\mathrm{N}$ was mainly affected by the ratio of $\mathrm{N}$ to phosphorus (N:P), for which we detected a significant positive correlation (Fig. 5 and Table S2 in Supplementary information). In contrast, dissolved $\mathrm{N}$ was negatively correlated with the TP and $\mathrm{N}$ contents of leaves. In addition, ammonium, nitrate, and MBN appeared to be mainly related to soil physical properties (i.e., water content, temperature, and BD), and nitrate was negatively correlated with leaf $\mathrm{N}$ content. Nitrogen levels in fine roots were positively correlated with rhizosphere TN and DN but negatively correlated with rhizosphere MBN. Moreover, leaf $\mathrm{N}$ was mainly negatively correlated with DN and nitrate and positively correlated with ammonium, whereas mulch $\mathrm{N}$ levels were positively correlated with $\mathrm{MBN}$ and negatively with ammonium.

\section{Discussion}

\section{Response of soil $\mathbf{N}$ fractions to organic mulching}

Contrary to our hypothesis, the OM5 treatment had significant effects on $\mathrm{N}$ fractions compared to those of the other two treatments, especially for rhizosphere MBN. The application of smaller amounts of organic mulch could contribute to enhancing relative decomposition and nutrient utilization by soil microorganisms because of the significant increase of MBN. Meanwhile, $\mathrm{N}$ immobilization could be increased when a large amount of mulch is added (Cao et al. 2018). Thick mulch prevents water from entering the soil and reduces the ability of plants to absorb water accompanied by low nitrate movement and accumulation toward the root surface, i.e., rhizosphere (Guo et al. 2002; Gorska et al. 2008). The $\mathrm{C} / \mathrm{N}$ ratio in the original soil was low (Table 1 ), and the decomposition of mulch consumed $\mathrm{N}$, which further enhanced the $\mathrm{N}$ limitation of the soil and thus did not significantly accelerate the element cycling in the soil with a large amount of mulch (Valenzuela-Solano and Crohn 2006). In addition, a large amount of organic mulch may restrict its own decomposition (N contents in OM10 and OM20 were higher than in OM5), preventing it from producing more 

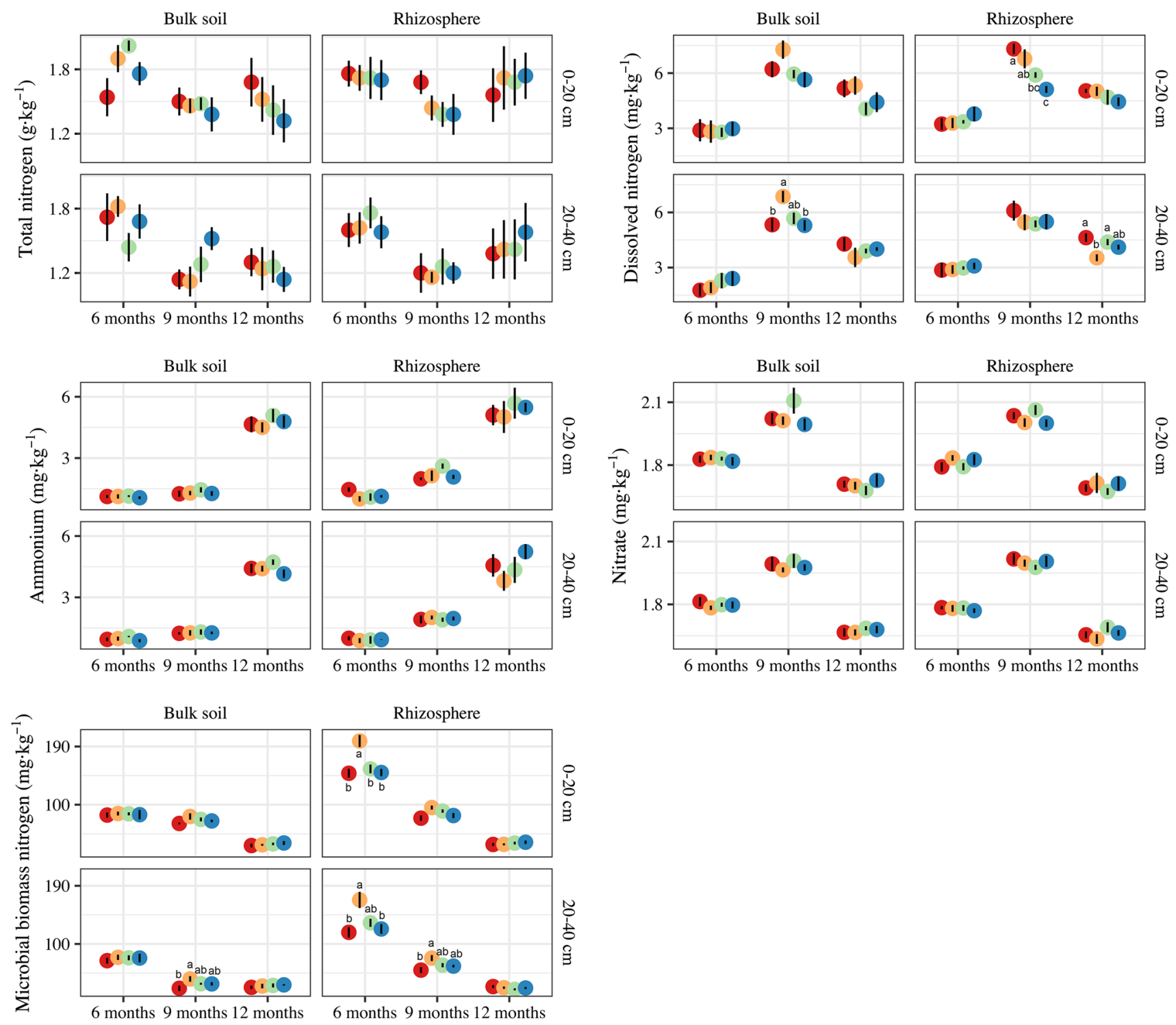

CK OM5

OM10

OM20

Fig. 3 Effects of organic mulching on soil nitrogen fractions in rhizosphere and bulk soils over time; error bars represent standard error of the mean (SE), values are means $\pm \mathrm{SE}(n=5)$. $C K$ control (no mulch), OM5 $5 \mathrm{~cm}(35 \mathrm{~kg})$ mulch, OM10 $10 \mathrm{~cm}(70 \mathrm{~kg})$ mulch,

available N. Accordingly, we speculate that frequent applications of small quantities of organic mulch might represent a beneficial strategy that favours $\mathrm{N}$ transformation and utilization in urban forests.

From the results, MBN is more sensitive than other $\mathrm{N}$ fractions to organic mulching, and $\mathrm{N}$ immobilization increased after mulching. Soil MBN is readily decomposed, which can be directly transformed into ammonium and nitrate through mineralization (Turner et al. 2017). Our results also revealed that MBN was correlated with $\mathrm{DN}$, ammonium, and nitrate. In addition, MBN was significantly
OM20 $20 \mathrm{~cm}(140 \mathrm{~kg})$ mulch. Different letters represent statistical differences among treatments at different soil depths and time after mulching according to Tukey's test $(P<0.05)$

correlated with soil physical properties (i.e., temperature, water content, and bulk density), which can be directly affected by mulching. Increases in MBN and the MBN: TN ratio were detected (Fig. 3, Fig. S1 and Table S4 in Supplementary information). Organic mulch-derived $\mathrm{N}$ assimilated by microorganisms, to a certain extent, may have contributed to reducing $\mathrm{N}$ loss via mineral $\mathrm{N}$ leaching. Moreover, the $\mathrm{pH}$ of bulk soil was correlated with MBN, although not as strongly as temperature, water content, or $\mathrm{BD} ; \mathrm{pH}$ was also an indicator of small changes in our study. In this regard, it has been found that $\mathrm{pH}$, owing to its prominent effects 


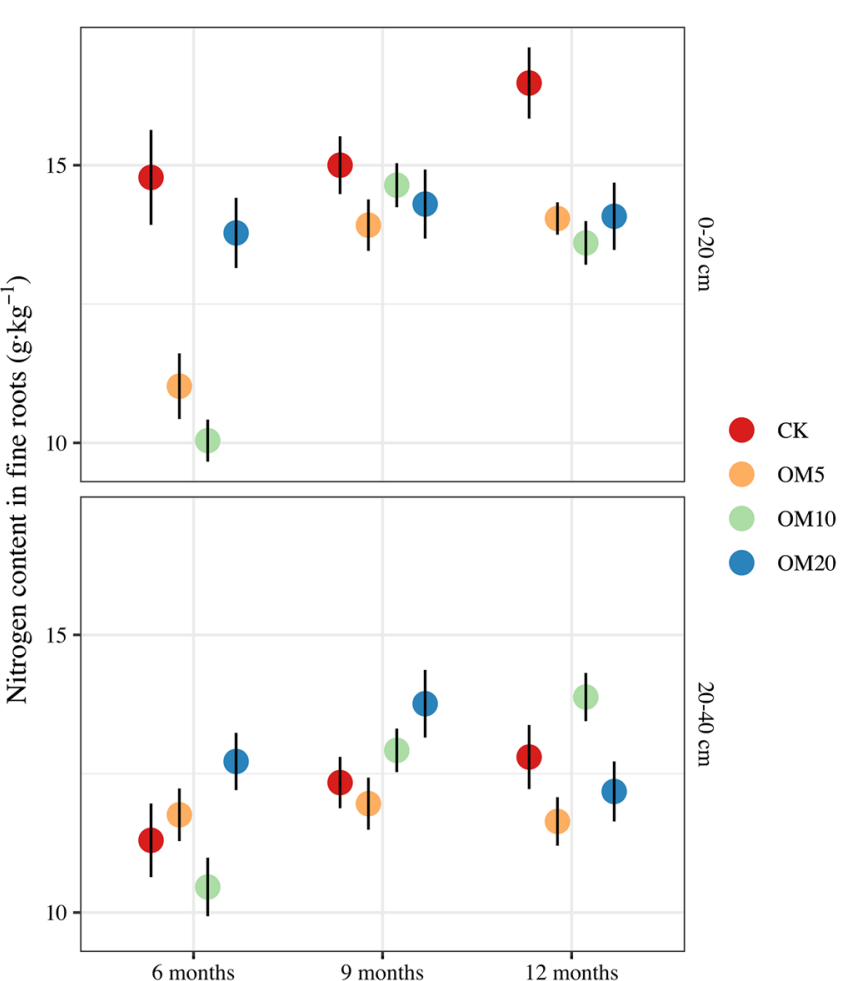

Fig. 4 Nitrogen content in fine roots, organic mulch and leaves over time after organic mulching ( $\mathrm{X}$ axis). Error bars represent standard error of the mean $(\mathrm{SE})$, values are means $\pm \mathrm{SE}(n=5)$. Different let-

on soil microorganisms, is an important factor affecting $\mathrm{N}$ mineralization and nitrification (Kader et al. 2013; Yao et al. 2018), and thus to a certain extent, may have an indirect influence on $\mathrm{N}$ fractions.

The results of the RDA revealed strong correlations between the $\mathrm{N}$ fractions and soil physical properties (temperature, water content, and $\mathrm{BD}$ ), whereas $\mathrm{TN}$ was affected to a greater extent by soil elements (i.e., carbon and phosphorus), indicating that $\mathrm{N}$ fractions are more susceptible to environmental factors, whereas $\mathrm{TN}$ tends to be more stable. The initial increase observed for $\mathrm{TN}$ in the topsoil can be attributed to the direct addition of organic mulch. Total $\mathrm{N}$ showed a significant positive correlation with the soil $\mathrm{N}$ : $\mathrm{P}$ ratio (Fig. 5, Table 3), and the addition of organic much resulted in a higher $\mathrm{N}$ : $\mathrm{P}$ ratio (Table 1 and Table 2), which in turn increased TN. However, TN began to decrease at the end of the growing season (9 months after mulching), which could be ascribed to changes in the $\mathrm{N}$ fractions (Fig. 3) and the ratios of these fractions to TN (Fig. S1, Table S4 in Supplementary information) during the growing season. Given that ammonium increased continuously, whereas nitrate initially increased and subsequently decreased, a greater quantity of nitrate underwent gaseous conversion via denitrification or was leached into the soil water at the end of the growing season (Smolander et al. 2019), with the latter

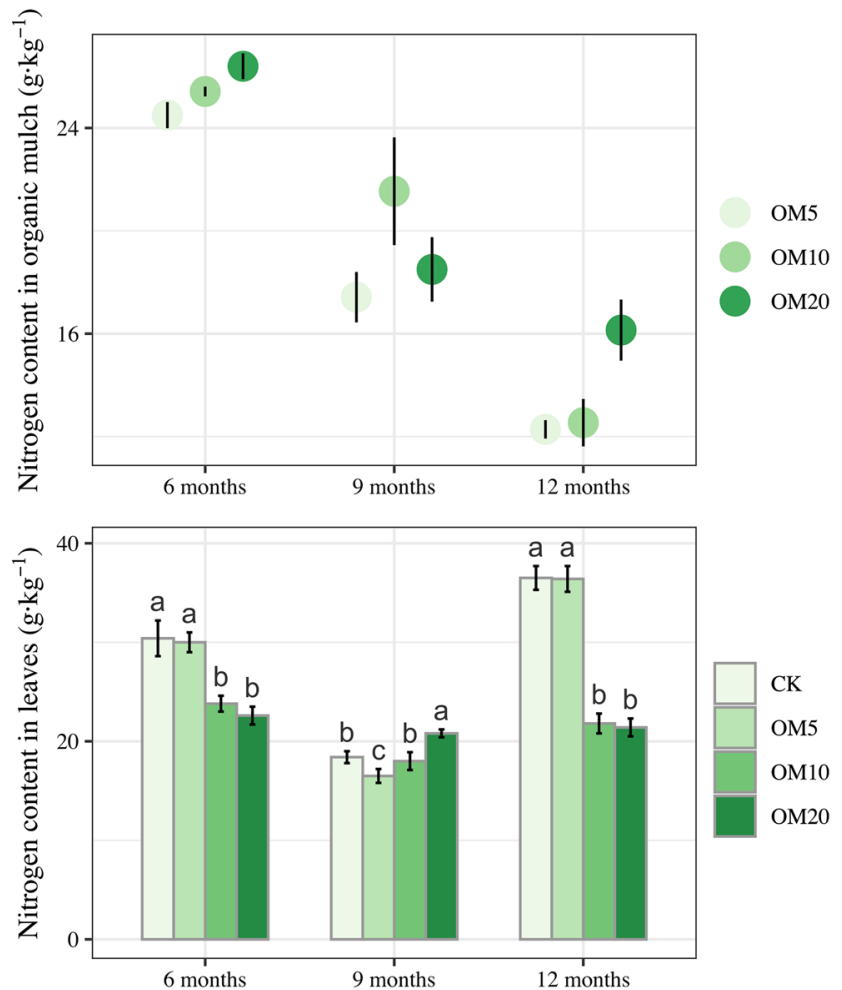

ters represent statistical differences among treatments at different soil depths and time after organic mulching according to Tukey's test $(P<0.05)$

effect being enhanced by a significant increase in rainfall during the summer. Meanwhile, nitrate may also have been taken up more by plants after organic mulching in the growing season. However, we found that rhizosphere TN showed the opposite trend to that of bulk soil, indicating that larger quantities of potentially labile $\mathrm{N}$ fractions were stimulated in the rhizosphere in response to organic mulching, which may be associated with $\mathrm{N}$ cycling, and that $\mathrm{TN}$ accumulated during the non-growing season (12 months after mulching).

Organic mulching has the effect of stimulating the available $\mathrm{N}$ in soil, and in response to this treatment, a greater quantity of available $\mathrm{N}$ is assimilated into the soil organic $\mathrm{N}$ pool by microbial activity (Mooshammer et al. 2014), given that $\mathrm{DN}$ in the topsoil increases during the early growth stage, whereas there is a corresponding decrease in the DN: TN ratio (Fig. S1, Table S4 in Supplementary information). The formation of DN is dependent on the rate of exchangeable $\mathrm{N}$ decomposition (Kalbitz et al. 2000), and in the present study, soil DN and ammonium increased at the beginning of the growing season (6 months after mulching), thereby indicating that the addition of organic mulch provides a greater quantity of available $\mathrm{N}$ for the soil. This may have the effect of enhancing nutrient exchange and increasing the generation of nitrate via nitrification. Dissolved nitrogen content is 


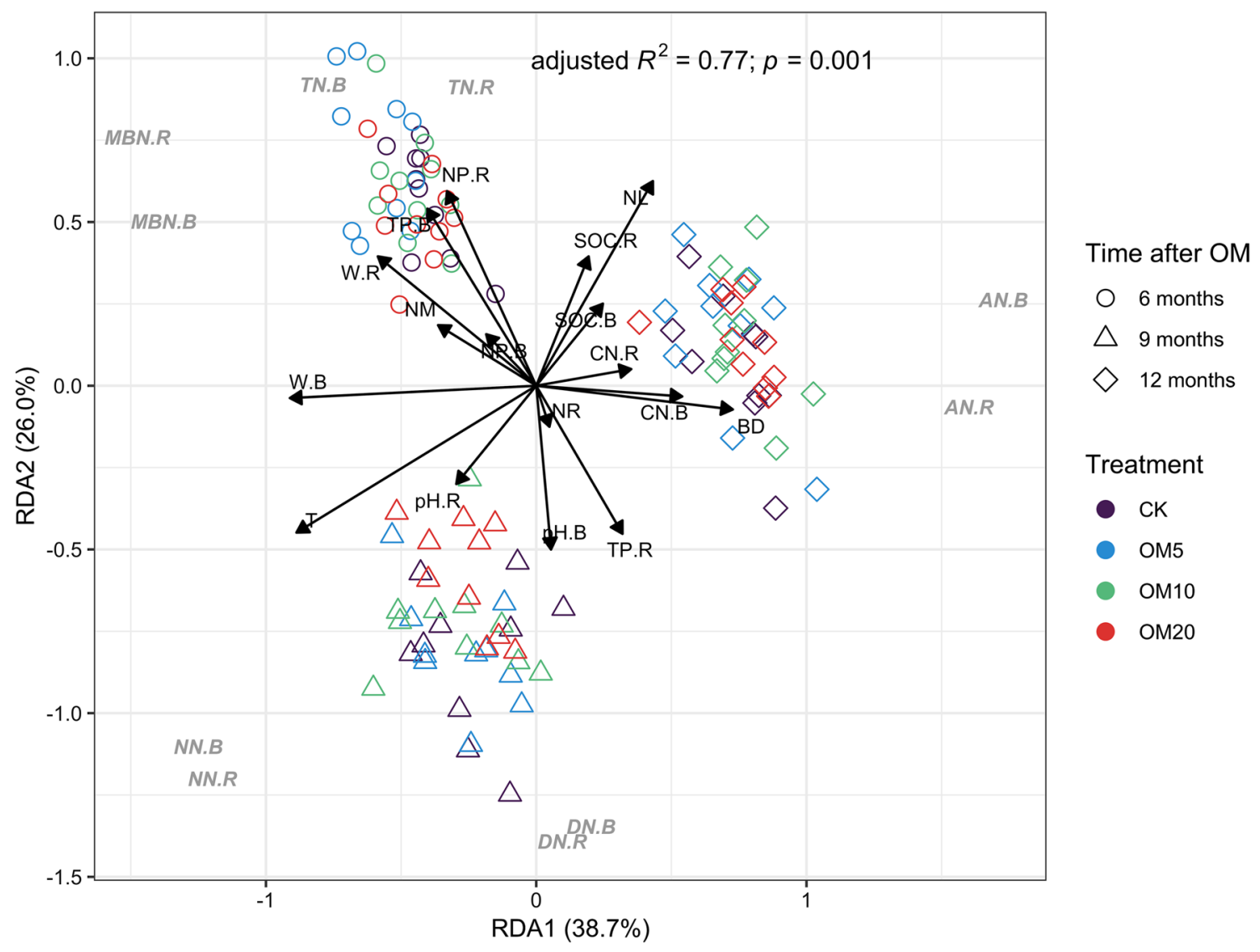

Fig. 5 Redundancy analysis (RDA) ordination plot of nitrogen fractions constrained by environmental variables that significantly explain variation. $T N$ total nitrogen, $D N$ dissolved nitrogen, $A N$ ammonium, $N N$ nitrate, $M B N$ microbial biomass nitrogen, $B D$ bulk density, $T$ temperature, $W$ water content, $S O C$ soil organic carbon, $C N$ ratio of carbon to nitrogen, $T P$ total phosphorus, $N P$ ratio of nitrogen to phosphorus, $N R$ nitrogen content in fine roots, $N L$ nitrogen content in leaves, $N M$ nitrogen content in organic mulch, $B$ in bulk soil, $R$ in rhizosphere, $C K$ control (no mulch), OM5 $5 \mathrm{~cm}$ (35 kg) mulch, OM10 $10 \mathrm{~cm}(70 \mathrm{~kg})$ mulch, OM20 $20 \mathrm{~cm}(140 \mathrm{~kg})$ mulch, $O M$ organic mulching

content of fine roots in the subsoil (DN correlated positively with fine root $\mathrm{N}$ content; Fig. 5).

On the basis of our results, it is speculated that organic mulching initially improves the soil physical environment and provides a direct source of available $\mathrm{N}$ which is assimilated into the soil $\mathrm{N}$ pool via microbial activity, resulting in increases in $\mathrm{TN}$ and $\mathrm{N}$ fractions. With time, copious rainfall during the growing season promoted the availability of $\mathrm{TN}$ in the topsoil, whereas a certain portion of the $\mathrm{N}$ fractions leached into deeper soil, and larger amounts of nitrate underwent gaseous conversion via denitrification. Although plants absorb large quantities of nutrients from the soil, the distribution of absorbed $\mathrm{N}$ across increasing plant biomass results in decreasing levels in both leaves and topsoil fine roots. Finally, during the dormant season, there were reductions in TN and DN, which could be attributed to the dry and cold conditions during winter, whereas rhizosphere TN and ammonium increased due to root outputs and direct 
changes in nutrient accumulation by plants. A large amount of organic mulch could improve the immobilization of inorganic $\mathrm{N}$ by microbes in the short term. In addition, the differences in correlations between the nitrogen levels of leaves, fine roots, and $\mathrm{N}$ fractions may be attributable to differences in the $\mathrm{N}$ utilization of leaves and fine roots (Ma et al. 2017).

\section{Rhizosphere MBN are more sensitive to organic mulching}

Microbial biomass nitrogen in the rhizosphere was more sensitive to mulching than bulk soil and more strongly affected by soil environmental changes. The rhizosphere is directly influenced by plant roots, and its associated nutrient composition, soluble organic matter content, enzyme activity, and microbial diversity are richer than those of bulk soil. Thus, it is associated with more rapid nutrient cycling and energy conversion and also makes a substantial contribution to the distribution of $\mathrm{N}$ in soil (Kuzyakov and Xu 2013). The results of the RDA indicated a better correlation between $\mathrm{N}$ content in fine roots, leaves, organic mulch, and most $\mathrm{N}$ fractions in the rhizosphere compared with those of bulk soil. Previous studies have consistently demonstrated a more prominent effect of fertilization on the rhizosphere than on bulk soil, thereby indicating that rhizosphere secretions play an important role in this process (Ai et al. 2012). Biochemical parameters in the rhizosphere explain better the changes in soil respiration and its components after nutrient addition, and compared with the bulk soil environment, available $\mathrm{N}$ in the rhizosphere is more closely correlated with soil respiration and its components (Liang et al. 2019). However, a limitation of this study is that neither root secretion nor soil respiration was examined to further understand the mechanisms of $\mathrm{N}$ transformation between plants and soil.

\section{Time and soil depth are important factors affecting soil $\mathbf{N}$ fractions}

The length of time after mulching (season) and soil depth were found to have a significant effect on $\mathrm{N}$ fractions studied, as well as soil physical and chemical properties (Table S3 in Supplementary information), and these two factors were more important than organic mulching itself in affecting the soil environment. Liu et al. (2018) suggested that soil N levels and cycling are more sensitive to temporal variations, while Wang et al. (2016) indicated that soil depth, rather than the sampling time or system of fertilization, has a more pronounced effect on $\mathrm{N}$ fixation. Our observations indicated that time makes a greater contribution to the $\mathrm{N}$ fractions than soil depth, whereas soil depth has a more prominent effect on total nitrogen than time. This also demonstrates that the labile $\mathrm{N}$ fractions are more affected by temporal variations that control soil moisture and temperature, whereas $\mathrm{TN}$ is more affected by accumulation processes regulated by soil nutrients, as discussed above. Furthermore, the results of these $\mathrm{N}$ fraction changes could be different as the time after mulching increases. For example, Kitou and Yoshida (1994) showed that mulching with plant residues increased $\mathrm{N}$ fixation in the early growth stage of soybean (Glycine max. L.) and improved soil fertility at later stages. Soil total organic $\mathrm{N}$ at a $0-20 \mathrm{~cm}$ depth increased with increasing time after gravel-sand mulching up until 11 years, and then decreased significantly between 11 and 16 years (Qiu et al. 2015). As this study only took samples in one year, this could be a limitation. However, interactions among time, soil depth, and treatment appeared to have no significant effects on most $\mathrm{N}$ fractions, presumably due to the complexities of the soil environment wherein they interact. Accordingly, more dynamic and long-term studies on the effects of organic mulching on the soil environment in forest ecosystems should be done to gain a better understanding of the interaction mechanisms.

\section{Conclusions}

Our results suggest that microbial biomass nitrogen is more sensitive than other nitrogen fractions to organic mulching, and MBN in rhizosphere was more sensitive than in bulk soil, and strongly affected by changes in the soil environmental. Total nitrogen and dissolved nitrogen were more susceptible to soil phosphorus limitations, whereas ammonium, nitrate, and MBN were strongly affected by physical factors of the soil environment such as temperature, water content, and bulk density. Time after mulching (season) and soil depth are important factors that need to be considered in research relating to soil nitrogen dynamics. Small quantities of organic mulch contribute to nitrogen decomposition and utilization, whereas a large amount of organic mulch improves nitrogen immobilization.

Acknowledgements We gratefully acknowledge the administration of the Dr. Sun Yat-sen Mausoleum for providing the experimental area and for the labour support at the site.

Authors' contributions Q Guan and X Sun conceived and designed the experiments, DL Jones developed methodology. X Sun and G Wang performed the experiments. X Sun and Y Ye analysed the data. X Sun wrote the manuscript; Q Ma provided editorial advice. 
Open Access This article is licensed under a Creative Commons Attribution 4.0 International License, which permits use, sharing, adaptation, distribution and reproduction in any medium or format, as long as you give appropriate credit to the original author(s) and the source, provide a link to the Creative Commons licence, and indicate if changes were made. The images or other third party material in this article are included in the article's Creative Commons licence, unless indicated otherwise in a credit line to the material. If material is not included in the article's Creative Commons licence and your intended use is not permitted by statutory regulation or exceeds the permitted use, you will need to obtain permission directly from the copyright holder. To view a copy of this licence, visit http://creativecommons. org/licenses/by/4.0/.References

Ai C, Liang G, Sun J, Wang X, Zhou W (2012) Responses of extracellular enzyme activities and microbial community in both the rhizosphere and bulk soil to long-term fertilization practices in a fluvo-aquic soil. Geoderma. https://doi.org/10.1016/j.geoderma. 2011.07.020

Bates D, Mächler M, Bolker BM, Walker SC (2015) Fitting linear mixed-effects models using lme4. J Stat Softw 1406(1):133-199. https://doi.org/10.18637/jss.v067.i01

Cao Y, Sun H, Zhang J, Chen G, Zhu H, Zhou S, Xiao H (2018) Effects of wheat straw addition on dynamics and fate of nitrogen applied to paddy soils. Soil Tillage Res. https://doi.org/10.1016/j.still. 2017.12.023

Chen Y, Sun TT, Qian HY, Fan JB, He YQ, Sun B (2016a) Nitrogen mineralization as a result of phosphorus supplementation in longterm phosphate deficient soil. Appl Soil Ecol. https://doi.org/10. 1016/j.apsoil.2016.04.019

Chen YL, Ding JZ, Peng YF, Li F, Yang GB, Liu L, Qin SQ, FangK YYH (2016b) Patterns and drivers of soil microbial communities in Tibetan alpine and global terrestrial ecosystems. J Biogeogr 43(10):1-13. https://doi.org/10.1111/jbi.12806

Chen YM, Xu X, Jiao XG, Sui YY, Liu XB, Zhang JY, Zhou K, Zhang JM (2018) Responses of labile organic nitrogen fractions and enzyme activities in eroded mollisols after 8-year manure amendment. Sci Rep. https://doi.org/10.1038/s41598-018-32649-y

Cheng Y, Wang J, Mary B, Zhang JB, Cai ZC, Chang SX (2013) Soil $\mathrm{pH}$ has contrasting effects on gross and net nitrogen mineralizations in adjacent forest and grassland soils in central Alberta, Canada. Soil Biol Biochem 57:848-857. https://doi.org/10.1016/j. soilbio.2012.08.021

Coppens F, Garnier P, De Gryze S, Merckx R, Recous S (2006) Soil moisture, carbon and nitrogen dynamics following incorporation and surface application of labelled crop residues in soil columns. Eur J Soil Sci 57(6):894-905. https://doi.org/10.1111/j.13652389.2006.00783.x

Dietrich G, Recous S, Pinheiro PL, Weiler DA, Schu AL, Rambo MRL, Giacomini SJ (2019) Gradient of decomposition in sugarcane mulches of various thicknesses. Soil Tillage Res 192:66-75. https://doi.org/10.1016/j.still.2019.04.022

Fu X, Wang J, Sainju UM, Liu W (2019) Aggregate size distribution and associated carbon and nitrogen in mulched winter wheat and spring corn. Can J Soil Sci 99(4):1-13. https://doi.org/10.1139/ cjss-2019-0015

Gorska A, Ye Q, Holbrook NM, Zwieniecki MA (2008) Nitrate control of root hydraulic properties in plants: translating local information to whole plant response. Plant Physiol 148(2):1159-1167. https:// doi.org/10.1104/pp.108.122499

Guignard MS, Leitch AR, Acquisti C, Eizaguirre C, Elser JJ, Hessen DO, Jeyasingh PD, Neiman M, Richardson AE, Soltis PS, Soltis DE, Stevens CJ, Trimmer M, Weider LJ, Woodward G, Leitch
IJ (2017) Impacts of nitrogen and phosphorus: From genomes to natural ecosystems and agriculture. Front Ecol Evol 5(5):70. https://doi.org/10.3389/fevo.2017.00070

Guo S, Brück H, Sattelmacher B (2002) Effects of supplied nitrogen form on growth and water uptake of French bean (Phaseolus vulgaris L.) plants: nitrogen form and water uptake. Plant Soil 239(2):267-275. https://doi.org/10.1023/A:1015014417018

Huang Z, Wan X, He Z, Yu Z, Wang M, Hu Z, Yang Y (2013) Soil microbial biomass, community composition and soil nitrogen cycling in relation to tree species in subtropical China. Soil Biol Biochem 62:68-75. https://doi.org/10.1016/j.soilbio.2013.03.008

Jiménez MN, Pinto JR, Ripoll MA, Sánchez-Miranda A, Navarro FB (2017) Impact of straw and rock-fragment mulches on soil moisture and early growth of holm oaks in a semiarid area. CATENA 152:198-206. https://doi.org/10.1016/j.catena.2017.01.021

Kader MA, Sleutel S, Begum SA, Moslehuddin AZM, De neve S (2013) Nitrogen mineralization in sub-tropical paddy soils in relation to soil mineralogy, management, $\mathrm{pH}$, carbon, nitrogen and iron contents. Eur J Soil Sci 64(1):47-57. https://doi.org/10. 1111/ejss. 12005

Kader MA, Senge M, Mojid MA, Ito K (2017) Recent advances in mulching materials and methods for modifying soil environment. Soil Tillage Res 168:155-166. https://doi.org/10.1016/j. still.2017.01.001

Kaiser C, Fuchslueger L, Koranda M, Gorfer M, Stange CF, Kitzler B, Rasche F, Strauss J, Sessitsch A, Zechmeister-Boltenstern S, Richter A (2011) Plants control the seasonal dynamics of microbial $\mathrm{N}$ cycling in a beech forest soil by belowground $\mathrm{C}$ allocation. Ecology 92(5):1036-1051. https://doi.org/10.1890/ 10-1011.1

Kalbitz K, Solinger S, Park J-H, Michalzik B, Matzner E (2000) Controls on the dynamics of dissolved organic matter in soils: a revies. Soil Sci 165(4):277-304. https://doi.org/10.1097/00010 694-200004000-00001

Kitou M, Yoshida S (1994) Mulching effect of plant residues on soybean growth and soil chemical properties. Soil Sci Plant Nutr 40(2):211-220. https://doi.org/10.1080/00380768.1994.10413295

Kuzyakov Y, Xu X (2013) Competition between roots and microorganisms for nitrogen: Mechanisms and ecological relevance. New Phytol 198(3):656-669. https://doi.org/10.1111/npy.12235

Liang G, Cai A, Wu H, Houssou AA, Ren C, Wang Z, Gao L, Wang B, Li S, Song X, Cai D (2019) Soil biochemical parameters in the rhizosphere contribute more to changes in soil respiration and its components than those in the bulk soil under nitrogen application in croplands. Plant Soil 435:111-125. https://doi.org/10.1007/ s11104-018-3886-0

Liu D, Huang Y, Yan H, Jiang Y, Zhao T, An S (2018) Dynamics of soil nitrogen fractions and their relationship with soil microbial communities in two forest species of northern China. PLoS ONE 13(5):e0196567. https://doi.org/10.1371/journal.pone.0196567

Lucas RW, Klaminder J, Futter MN, Bishop KH, Egnell G, Laudon H, Högberg P (2011) A meta-analysis of the effects of nitrogen additions on base cations: implications for plants, soils, and streams. For Ecol Manag 262(2):95-104. https://doi.org/10.1016/j.foreco. 2011.03.018

Ma Q, Cao X, Xie Y, Xiao H, Tan X, Wu L (2017) Effects of glucose on the uptake and metabolism of glycine in pakchoi (Brassica chinensis L.) exposed to various nitrogen sources. BMC Plant Biol 17(5968):1008-1010. https://doi.org/10.1186/s12870-017-1006-6

Meier CL, Bowman WD (2008) Links between plant litter chemistry, species diversity, and below-ground ecosystem function. Proc Natl Acad Sci 105(50):19780-19785. https://doi.org/10.1073/ pnas.0805600105

Meier IC, Finzi AC, Phillips RP (2017) Root exudates increase N availability by stimulating microbial turnover of fast-cycling $\mathrm{N}$ pools. 
Soil Biol Biochem 106:119-128. https://doi.org/10.1016/j.soilb io. 2016.12.004

Mikutta R, Turner S, Schippers A, Gentsch N, Meyer-Stüve S, Condron LM, Peltzer DA, Richardson SJ, Eger A, Hempel G, Kaiser K, Klotzbücher T, Guggenberger G (2019) Microbial and abiotic controls on mineral-associated organic matter in soil profiles along an ecosystem gradient. Sci Rep 9(1):20194. https://doi.org/10.1038/ s41598-019-46501-4

Mooshammer M, Wanek W, Hämmerle I, Fuchslueger L, Hofhansl F, Knoltsch A, Schnecker J, Takriti M, Watzka M, Wild B, Keiblinger KM, Zechmeister-Boltenstern S, Richter A (2014) Adjustment of microbial nitrogen use efficiency to carbon: nitrogen imbalances regulates soil nitrogen cycling. Nat Commun 5:3694. https://doi.org/10.1038/ncomms4694

Oksanen J, Blanchet FG, Friendly M, Kindt R, Legendre P, Mcglinn D, Minchin PR, O'hara RB, Simpson GL, Solymos P, Henry M, Stevens H, Szoecs E, Maintainer HW (2019) vegan: Community Ecology Package. R package version 2.5-5. https://CRAN.R-proje ct.org/package=vegan. Community Ecol Packag

Pal PK, Mahajan M (2017) Tillage system and organic mulch influence leaf biomass, steviol glycoside yield and soil health under subtemperate conditions. Ind Crops Prod 104:33-44. https://doi.org/ 10.1016/j.indcrop.2017.04.012

Pastor J, Post WM (1986) Influence of climate, soil moisture, and succession on forest carbon and nitrogen cycles. Biogeochemistry 2(1):3-27. https://doi.org/10.1007/BF02186962

Qiu Y, Xie ZK, Wang YJ, Malhi SS, Ren JL (2015) Long-term effects of gravel-sand mulch on soil organic carbon and nitrogen in the Loess Plateau of northwestern China. J Arid Land 1:46-53. https://doi.org/10.1007/s40333-014-0076-7

R Development Core Team (2018) R: A language and environment for statistical computing. Vienna, Austria. ISBN 3-900051-07-0. http://www.R-project.org.

Ren C, Sun P, Kang D, Zhao F, Feng Y, Ren G, Han X, Yang G (2016) Responsiveness of soil nitrogen fractions and bacterial communities to afforestation in the Loess Hilly Region (LHR) of China. Sci Rep 6:28469. https://doi.org/10.1038/srep28469

Rose TJ, Keen B, Morris SG, Quin P, Rust J, Kearney L, Kimber S, Van Zwieten L (2016) Application of woody biochar and woody mulch to mitigate nitrous oxide emissions from a poultry litter-amended soil in the subtropics. Agric Ecosyst Environ 228:1-8. https://doi. org/10.1016/j.agee.2016.05.004

Smolander A, Törmänen T, Kitunen V, Lindroos AJ (2019) Dynamics of soil nitrogen cycling and losses under Norway spruce logging residues on a clear-cut. For Ecol Manage 449:117444. https://doi. org/10.1016/j.foreco.2019.06.041

Templer P, Findlay S, Lovett G (2003) Soil microbial biomass and nitrogen transformations among five tree species of the Catskill Mountains, New York, USA. Soil Biol Biochem 35(4):607-613. https://doi.org/10.1016/S0038-0717(03)00006-3

Turner S, Meyer-Stüve S, Schippers A, Guggenberger G, Schaarschmidt F, Wild B, Richter A, Dohrmann R, Mikutta R (2017) Microbial utilization of mineral-associated nitrogen in soils. Soil Biol Biochem 104:185-196. https://doi.org/10.1016/j.soilbio. 2016.10.010
Usowicz B, Lipiec J (2017) Spatial variability of soil properties and cereal yield in a cultivated field on sandy soil. Soil Tillage Res 174:241-250. https://doi.org/10.1016/j.still.2017.07.015

Valenzuela-Solano C, Crohn DM (2006) Are decomposition and N release from organic mulches determined mainly by their chemical composition? Soil Biol Biochem 38(2):377-384. https://doi.org/ 10.1016/j.soilbio.2005.06.002

Vitousek PM, Aber JD, Howarth RW, Likens GE, Matson PA, Schindler DW, Schlesinger WH, Tilman DG (1997) Human alteration of the global nitrogen cycle: Sources and consequences. Ecol Appl 7(3):737-750. https://doi.org/10.1890/1051-0761(1997)007[0737: HAOTGN]2.0.CO;2

Wang J, Zhang D, Zhang L, Li J, Raza W, Huang Q, Shen Q (2016) Temporal variation of diazotrophic community abundance and structure in surface and subsoil under four fertilization regimes during a wheat growing season. Agric Ecosyst Environ 216:116124. https://doi.org/10.1016/j.agee.2015.09.039

Wang F, Wang J, Wang Y (2019) Using multi-fractal and joint multifractal methods to characterize spatial variability of reconstructed soil properties in an opencast coal-mine dump in the Loess area of China. CATENA 182:104111. https://doi.org/10.1016/j.catena. 2019.104111

Wild B, Schnecker J, Knoltsch A, Mooshammer M, Gentsch N, Mikutta R, Alves RJE, Gittel A, Lashchinskiy N, Richter A (2015) Microbial nitrogen dynamics in organic and mineral soil horizons along a latitudinal transect in western Siberia. Global Biogeochem Cycles 29(5):567-582. https://doi.org/10.1002/2015GB005084

Yao X, Zhang N, Zeng H, Wang W (2018) Effects of soil depth and plant-soil interaction on microbial community in temperate grasslands of northern China. Sci Total Environ 630:96-102. https:// doi.org/10.1016/j.scitotenv.2018.02.155

Yokobe T, Hyodo F, Tokuchi N (2018) Seasonal effects on microbial community structure and nitrogen dynamics in temperate forest soil. Forests 52(3):470-479. https://doi.org/10.3390/f9030153

Zhang H, Pang H, Zhao Y, Lu C, Liu N, Zhang X, Li Y (2020) Water and salt exchange flux and mechanism in a dry saline soil amended with buried straw of varying thicknesses. Geoderma 365:114213. https://doi.org/10.1016/j.geoderma.2020.114213

Zhou ZH, Wang CK (2015) Soil resources and climate jointly drive variations in microbial biomass carbon and nitrogen in China's forest ecosystems. Biogeosciences Discuss 12(14):6751-6760. https://doi.org/10.5194/bgd-12-11191-2015

Zhou WJ, Sha LQ, Schaefer DA, Zhang YP, Song QH, Tan ZH, Deng Y, Deng XB, Guan HL (2015) Direct effects of litter decomposition on soil dissolved organic carbon and nitrogen in a tropical rainforest. Soil Biol Biochem 81:255-258. https://doi.org/10. 1016/j.soilbio.2014.11.019

Publisher's Note Springer Nature remains neutral with regard to jurisdictional claims in published maps and institutional affiliations. 